\title{
The Necessity Of Strategic Leadership In Corporate Sustainability
}

\author{
John Theodore, JDT Management Consultants, USA
}

\begin{abstract}
The purpose of this article is to present the necessity of having strategic leadership in business corporations that practice corporate sustainability. There are three areas that corporate sustainability focuses upon: Ecological, sociological, and corporate/business. Corporate sustainability requires strategic leadership in order to interact with these three dynamic and divergent areas. Strategic leaders communicate their vision to their managers and employees and remain in continuous and uninterrupted contact with the former who are dexterously empowered by their leaders to assume supportive roles for the communication of their leaders' strategic vision to internal and external stakeholders of the organization. Strategic thinking is utilized by strategic leaders and has to do with the analysis and evaluation of the existing internal and external environments of the organization and that of how changes in both environments can affect the organization. Strategic leaders utilize strategic intent that includes focusing the organization's intention to operate strategically. Flexibility is the ability of strategic leaders to analyze, evaluate, and respond to changes in both the internal and external environment of their organizations. Strategic leaders initiate changes because of the demands that emanate from the external and the internal environments of the organization. Strategic leadership changes are dramatic ones and their implementation requires the integration of vision, flexibility, and the support of the managers of the organization.
\end{abstract}

Keywords: Corporation; Corporate Strategy; Strategic Leadership; Sustainability; Internal Environment; External Environment

\section{THE BUSINESS CORPORATON}

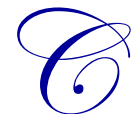

hief Justice John Marshall of the United States Supreme Court provided the definition of the American corporation in 1819 by stating that "it is an artificial being, invisible, intangible, and existing only in the contemplation of the law" (Epstein, 1969, p. 18). By being a legal entity, the law recognizes the corporation as having independent/separate existence from its owners, employees, managers, and directors. The corporation's birth certificate is the corporate charter that establishes its existence.

There are government corporations and private/business corporations in the United States. Business corporations in the country are approximately $20 \%$ of the total legal forms of business enterprises-proprietorships and partnerships are the other two legal forms-but produce close to $90 \%$ of the revenues. They are powerful economic and political entities in the nation. Small business corporations are privately held by being owned by a small number of investors, whereas most of the business corporations are publically held which means that their shares (certificates of ownership) are being purchased and sold on a daily basis. In "the United States and the United Kingdom most large firms are widely held, while most large firms elsewhere are controlled by a few wealthy families" (Morck, 2007, p. 4). This article focuses on the publically held business corporations.

In reference to the social responsibility of business corporations from the beginning of the 1800 s to the end of World War II, they were considered amoral, that is being both moral and immoral depending on the conditions that provided them with the most profits. Even today, "corporate social responsibility is like the call boxes. It holds out promises of help, reassures people, and sometimes works" (Bakan, 2004, p. 50). 
In order for the business corporation to continue its successful operation today it "still needs to franchise from society, and the terms of that franchise still matter enormously. Two clouds have gathered on the horizon: the cloud of corporate scandals and that of social responsibility" (Micklethwait \& Wooldridge, 2005, p. 186).

\section{CORPORATE SUSTAINABILITY}

The formal definition of sustainability is "that sustainable development is the development that meets the needs of the present without compromising the ability of the future generations to meet their own needs" (World Commission, 1987, p. 43). Corporate sustainability has to do with the corporate contributions "toward the wealth of the planet, the survival of humans and other species, the development of a just and humane society, and the creation of work that brings dignity and self-fulfillment to those undertaking it" (Dunphy, Griffiths, \& Benn, 2007, p. 3). A second definition indicates that corporate sustainability can be viewed "as a new and evolving management philosophy that addresses organizational growth and profitability, environment protection, social justice, and equality (economic/environmental/social" (Fisher, 2010, p. 3). A third definition states that corporate sustainability describes the "inputs, processes, outputs, and outcomes necessary to implement a successful sustainability strategy; the inputs include the external context, the internal context, the business context, and the human and financial resources" (Epstein, 2008, p. 26).

According to the elements of the above-cited definitions, there are three areas that corporate sustainability focuses upon. The first is the ecological area and entails meeting the needs of the present by effectively and efficiently using the wealth of the planet without compromising the ability of the future generations to meet their own needs, the survival of humans and other species, and ecological justice and equality. This entails the macro external environment of the organization. The second area is sociological and pivots around the development of a just and humane society, the creation of work that brings dignity and self-fulfillment to those undertaking it, and economic justice and equality. This, too, has to do with the macro external environment of the organization. The third area addresses the internal environment and points at organizational growth, profitability, the functional units, the hierarchy, and the principles of organization. It also addresses the micro/industrial external environment of the organization.

Corporate sustainability interacts with ecology under the auspices of the ecological modernization theory which rests upon the concept that the economies and the politics of developed capitalist systems are not conflicting with the environmental (York, Rosa, \& Dietz, 2003). Periodically one encounters pessimistic persons who think that ecological sustainability cannot be attained because of the current degree of ecological damage. Ecological experts have a different opinion, however, and indicate that: "Life is robust. Restoration can be made. Everything but extinction can be made better. So there is reason for hope. We can think of our work as saving things that will come back stronger later" (Assadourian, Prugh, \& Startk, 2013, p. 375).

The role of the corporation in this case is to provide continuous assistance to the ecological environment and make every attempt to avoid conflict with it. "Corporate and social responsibility enables an organization's mission and acts as a guide to what the company stands for and will uphold for its customers" (Brockett \& Rezaee, 2012, p. 152). Corporate leaders who are able to develop strategies to deal positively with environmental issues gain advantage over their competitors. Seeking out opportunities that can be "considered a play to win strategy that has the explicit goal of investing in innovation to produce significant advantage that the competition will not be able to easily or quickly match" (Epstein, 2008, p. 63).

Strategic corporate leaders have vision in order to mark the direction they have selected in meeting ecological challenges and anticipate events; use strategic thinking and strategic intent to cover the entire ecological area with which the organization interacts; flexibility to face drastic and divergent changes in ecology; and the ability to initiate and implement the necessary changes in order to interact effectively, efficiently, and on a timely basis with the changes demanded by the ecological environment.

Corporate sustainability, in reference to the sociological environment, has been recently viewed as a social contract between the corporation and society. The social contact provides the rationale for the corporation's continued existence for it "defines the mutually valuable exchanges that will sustain the firm's ongoing network of 
relationships. It also defines the organization's mission and legitimizes right to operate and produce its goods and services" (Dunphy, Griffiths, \& Benn, 2007, p. 69).

Strategic corporate leaders have vision in order to determine the direction of the organization in the sociological area and anticipate changes; have flexibility to work with expected and unexpected sociological changes; initiate and implement the necessary sociological changes; and employ strategic thinking and strategic intent to embrace the entire sociological external environment.

The internal and micro/industry environments of the organization include the internal operations of the functional units - production and operations, marketing and sales (which are also functioning in the micro/external environment); finance and accounting; human resources; the principles of organization; and the organizational hierarchy. An organization's sustainability posture and performance "have a number of effects on its ability to anticipate and effectively address business risks and opportunities as well as its residence in the inevitable surprises that characterize the human landscape" (Soya, 2012, p. 97).

In order for corporate leaders to perform effectively and efficiently in this area, they have vision that provides them direction in both internal and micro/industry external operations, strategic thinking and strategic intent to cover all the areas of business and corporate-level operation on a short and long-term basis, flexibility to work with internal and external changes, and the ability to initiate and implement changes demanded by both the business and the corporate levels of the organization. Embracers of sustainability can be seen as those who have solid "commitment to sustainable practices in their operations and who are pushing those practices through their supply chains. They view sustainability as a pathway toward gaining a competitive edge and increasing market share" (Farver, 2013, p. 31).

\section{STRATEGIC LEADERSHIP}

Corporate sustainability requires strategic leadership in order for corporate leaders to think strategically and use strategic intent, anticipate events in order to be proactive, have flexibility in order to work correctly with divergent situations and interact with the internal and external environments, and initiate and implement changes.

Leadership is defined as a "long-term relationship, or partnership, between leaders and group members" (Durbin, 2010, p. 4). Another definition indicates that leadership "is the process whereby an individual influences others to achieve a common goal" (Kreitner \& Kinicki, 2008, p. 465). Strategic leadership is defined "as a person's ability to anticipate, envision, maintain flexibility, think strategically, and work with others to initiate changes that will create a viable future for the organization" (Barnett, Greve, \& Park, 1994, pp. 11-28). Another definition on strategic leadership indicates that "CEOs who use strategic leadership believe that their most important job is to create, test, and design the implantation of long-term strategy, extending in some case into the distant future" (Farkas \& Welaufer, 1992, p. 116). Finally, a third definition states that strategic leadership "is a leader's ability to anticipate events, and maintain flexibility and a long-term perspective to guide the organization" (Christiansen, 1997, pp. 141-150). The key elements imbedded in the above-cited definitions of strategic leadership are ability to envision and anticipate events; have flexibility; think strategically; initiate developmental changes; and create, test, and design the implementation of long term strategies to guide the organization.

Vision is defined as "an ambitious view that offers a future that is better in important ways than what now exists" (Hamel \& Prahalad, 1994, pp. 127-128). Bennis and Nanus conducted several experiments on strategic leadership vision and stated that "our research has indicated that one of the most critical elements of successful leadership was a clear articulated vision, or sense of direction, to focus the attention of everyone associated with the organization" (2007, p. 62).

Strategic leaders communicate their vision to their managers and employees and remain in continuous and uninterrupted contact with the former who are dexterously empowered by their leaders to assume supportive roles for the communication of their leaders' strategic vision to internal and external stakeholders of the organization. The supportive roles of the subordinates can be under continuous development through the coaching activities by their strategic leaders. Such leaders actively seek out ways to increase choice, providing greater decision-making 
authority and responsibility for their constituents. They also "develop the capabilities of their team and foster selfconfidence through the faith they demonstrate in letting other people lead" (Kouzes \& Posner, 2002, p. 287). This is the beginning of creating learning organizations that enhance the knowledge of the human factor to better understand the firm's external environment and how such an organization is functioning within the micro and macro external environment on a domestic and global basis (Theodore, 2012).

In this section, it is necessary to mention the importance of organizational structures within which strategic leaders function. A "structural scenario casts leaders in the fundamental roles of clarifying goals, attending to the relationship between structure and environment, and developing a clearly defined array of roles and relationships appropriate of what needs to be done" (Boleman \& Deal, 2008, p. 329).

Strategic thinking is utilized by strategic leaders and has to do with the analysis and evaluation of the existing internal and external environments of the organization and that of how changes in both environments can affect the organization. The need "for continuous strategic thinking becomes especially important as every organization in every industry confronts a variety of challenges every day" (Pitts \& Lei, 2003, p. 25). By employing strategic thinking, strategic leaders make conscious choices as to how they use their limited resources in today's dynamic external environment that is subject to the omnipresent forces of change. Strategic leaders, therefore, depend on their strengths, knowledge, skills, capabilities, and other personal and professional assets and qualities in order to meet the mission, goals, and objectives of the organization.

The writer of this article wanted to also include the elements of strategic intent and ethical decision-making which are related to strategic thinking. Strategic intent includes focusing the organization's intention on the essence of "winning; motivating people by communicating the value of the target; leaving room for individual and team contributions; sustaining enthusiasm by providing new operational definitions as circumstances change; and using intent consistently to guide resource allocations" (Hamel \& Prahalad, 1989, pp. 63-74). Ethical decision making includes the "recognition of the problem, making some kind of moral judgment about the issue, establishing an intention to act upon that judgment, and acting according to their intentions" (Crane \& Matten, 2010, p. 143). Correct ethical practices create a strong credibility for the organization among all internal and external stakeholders. "The creditability of leadership will have the greatest impact on maintaining the positive reputation of business in the future. The message that emanates from leadership shapes the culture of an organization and facilitates reform" (Brady, 2005, p. 121).

Flexibility is the ability of strategic leaders to "analyze, evaluate and respond to changes in both the internal and external environments of their organizations" (Shimizu \& Hitt, 2004, pp. 45-47). Flexibility has become a modus operandi among strategic leaders who are adaptable to the ever-changing environmental conditions nationally and globally. Strategic leaders delegate flexibility to their management and such flexibility is supported through appropriate management training that includes job rotation, thus enabling the managers to familiarize themselves with the total operation of the organization. The managers acquire a holistic view of the organization which provides them with a strong familiarity of its operation. The acquired flexibility and familiarity enables the managers to increase their support for their strategic leaders and farther enhance the flexibility of strategic leadership and the effectiveness of their leaders. Leaders are effective "when their followers achieve their goals, can function well together, and can adapt to the changing demands of the external forces" (Nahavandi, 2006, p. 6).

\section{Initiation of Changes}

Strategic leaders initiate changes because of the demands that emanate mainly from the external environment and to a lesser extent from the internal environment of the organization. Because "external forces have global effects, they cause an organization to question the essence of its operation, whereas internal forces come from human resource problems and managerial behavioral decisions" (Kinicki \& Kreitner, 2006, pp. 393-395). Kotter has indicated that the external forces that have demanded changes during the last fifty years are technological, the international economic integration, the maturation of markets in developing countries, and the fall of communist and socialist regimes (1996). In reference to strategic leaders designing the implementation of long-term strategies, Scharmer and Kaufer stated that "strategic is about connecting, stepping into, and acting from the field of the future that wants to emerge" (2013, p. 114) and call this leadership quality presencing which is a hybrid word from sensing 
and presence (the state of being in the present moment) and means sensing and actualizing one's highest future possibility — acting from the presence of what is wanting to emerge (Scharmer \& Kaufer, 2013).

\section{Implementation of Changes}

Strategic leadership faces changes that are dramatic and their implementation requires the integration of vision, flexibility, and the support of the managers of the organization who have received and accepted such flexibility and who are willing and ready to work closely with their strategic leaders to timely, effectively, and efficiently implement such changes. Here, strategic leaders must overcome resistance to change by the human factor of the organization. From a "human resource perspective, people have good reason to resist changes. Sometimes resistance is sensible because the new methods are a management mistake that would take the organization in the wrong direction" (Boleman \& Deal, 2008, p. 381). Strategic leaders reduce/eliminate resistance to change by involving those who will be affected by the change in the change process. Research in the area of overcoming resistance to change indicated that the assistance the human factor receives from strategic leaders is of paramount importance. "We have seen many instances in which such support can offer not just the hope of change, but also the confidence to embrace such hope." (Goleman, Boyatzis, \& McKee, 2002, p. 162).

\section{SUMMARY}

The purpose of this article was to present the necessity of having strategic leadership in corporate sustainability. There are three areas corporate sustainability focuses upon. The first is the ecological area and entails meeting the needs of the present by effectively and efficiently using the wealth of the planet without compromising the ability of the future generations to meet their own needs, the survival of humans and other species, and ecological justice and equality. The second area is the sociological one that pivots around the development of a just and humane society, the creation of work that brings dignity and self-fulfillment to those undertaking it, and economic justice and equality. The third area addresses the internal environment that consist of organizational growth; profitability; the principles of organization; the organizational hierarchy; the functional units; and the micro/industry environment of the organization.

Corporate sustainability requires strategic leadership in order to meet its mission, goals, and objectives effectively, efficiently, and on a timely basis. Strategic leaders have vision in order to define the direction of the organization's internal environment and to anticipate changes in the external one. Strategic thinking is utilized by strategic leaders and has to do with the analysis and evaluation of the existing internal and external environments of the organization and that of how changes in both environments can affect the organization. Strategic intent and ethical-decision making are also used by strategic leaders and includes focusing the organization's intention on the essence motivating people by communicating the value of the target; leaving room for individual and team contributions; sustaining enthusiasm by providing new operational definitions as circumstances change; and using intent ethically and consistently to guide resource allocations.

Flexibility is the ability of strategic leaders to analyze, evaluate, and respond to changes in both the internal and external environment of their organizations. Strategic leaders initiate changes because of the demands that emanate from the external and the internal environment of the organization. Finally, strategic leaders implement changes which are dramatic and their implementation requires the integration of vision, flexibility, and the support of the managers of the organization who have received and accepted such flexibility and who are willing and ready to work closely with their strategic leaders to timely, effectively and efficiently implement such changes.

\section{AUTHOR INFORMATION}

Dr. John Theodore is the holder of a Ph.D. degree in Administration and Latin American Studies from the University of Kansas; a Ph.D. in Management from the Aristotelian University in Greece, European Union; and a D.B.A. in International Business from the University of South Africa. He has been teaching and consulting for four decades domestically and internationally. He is a visiting professor in various foreign universities. Dr. Theodore is the president of JDT Management Consultants in Clearwater, Florida, specializing in management, organization, strategy, international business, human resources, organizational development, and educational administration. He is 
a certified management consultant (CMC) certified by the Institute of Management Consultants in Washington, D.C. E-mail: jdtheodore@tampabay.rr.com

\section{REFERENCES}

1. Assadourian, E., Prugh, T., \& Starke, L. (2013). Is sustainability still possible? Washington, D.C.: Island Press.

2. Bakan, J. (2004). The corporation: The pathological pursuit of profit and power. New York: The Free Press.

3. Barnett, W. P., Greve, H. R., \& Park, D. Y. (1994). An evolutionary model of organizational performance. Strategic Management Journal, 15(S1), 11-28. doi: 10.1002/smj.4250150903

4. Bennis, W. G., \& Nanus, B. (2007). Leaders: Strategies for taking charge. New York: Harper Collins Publishers.

5. Bolman, L. G., \& Deal, T.E. (2008). Reframing organizations: Artistry, choice, and leadership (4 $4^{\text {th }}$ ed.). San Francisco: John Wiley \& Sons.

6. Brady, A. K. O., (2005). The sustainability effect: Rethinking corporate reputation in the $21^{\text {st }}$ century. New York. Palgrave-McMillan.

7. Brockett, A., \& Rezaee, Z. (2012). Corporate sustainability: Integrating performance and reporting. Hoboken. NJ: John Wiley \& Sons.

8. Christiansen, C. M. (1997). Making strategy: Learning by doing. Harvard Business Review, 75(6), 141150 .

9. Crane, A., \& Matten, D. (2010). Business ethics ( $3^{\text {rd }}$ ed.). Oxford: Oxford University Press.

10. Dunphy, D. C., Griffiths, A., \& Benn, S. (2007). Organizational change for corporate sustainability: A guide for leaders and change agents of the future. New York: Routledge.

11. Durbin, A. J. (2010). Leadership: Research, findings, practices, and skills (6 $6^{\text {th }}$ ed.). Mason, OH. SouthWestern.

12. Epstein, E. M. (1969). The corporation in American politics. Englewood Cliffs, NJ: Prentice Hall, Inc.

13. Epstein, M. J. (2008). Making sustainability work: best practices in managing and measuring corporate social, environmental and economic impacts. San Francisco: Berrett-Koehler Publishers, Inc.

14. Farkas, C. M., \& Wetlaufer, S. (1992). The ways chief executive officers lead. Harvard Business Review of Leadership, n.v., 116.

15. Farver, S. (2013). Mainstreaming corporate sustainability: Using proven tools to promote business success. Cotani, CA: GreenFix, LLC.

16. Fisher, D. C. (2010). Corporate sustainability planning assessment guide: A comprehensive organizational assessment. Milwaukee, WI: Quality Press.

17. Goleman, D., Boyatzis, R. E., \& McKee, A. (2002). Primal leadership: Realizing the power of emotional intelligence. Boston: Harvard Business School Publishing.

18. Hamel, G., \& Prahalad, C. K. (1989, May-June). Strategic intent. Harvard Business Review, n.v., 63-74.

19. Hamel G., \& Prahalad, C. K. (1994, July-August). Competing for the future. Harvard Business Review, n.v., 127-128.

20. Kotter, J. P. (1996). Leading change. Boston: Harvard Business School Press.

21. Kouzes, J. M., \& Posner, B. Z. (2002). Leadership challenge. San Francisco. John Wiley \& Son.

22. Kreitner, R., \& Kinicki, A. (2008). Organizational behavior ( $8^{\text {th }}$ ed.). Boston: McGraw-Hill Irwin.

23. Kinicki, A., \& Kreitner, R. (2006). Organizational behavior ( $2^{\text {nd }}$ ed.). Boston: McGraw-Hill Irwin.

24. Micklethwait, J., \& Wooldridge, A. (2005). Redefining global strategy. New York: Modern Library Chronicles.

25. Morck, R. K. (2007). A history of corporate governance around the world: Family business groups to professional managers. Chicago: The University of Chicago Press.

26. Nahavandi, A. (2006). The art and science of leadership. Upper Saddle River, NJ: Prentice Hall.

27. Pitts, R., \& Lei, D. (2003). Strategic management. Mason, OH: South-Western.

28. Scharmer, O., \& Kaufer, K. (2013). Leading from the emerging future: From ego-system to eco-system economics. San Francisco, CA: Berrett-Kohler, Publishers, Inc.

29. Shimizu, K., \& Hitt, M. A. (2004) Strategic flexibility: Organizational preparedness to reverse ineffective strategic decisions. The Academy of Management Executive, 18(4), 44-47. 
30. Soyka, P. A. (2012). Creating a sustainable organization: Approaches for enhancing corporate value through sustainability. Upper Saddle River, NJ: Pearson Education, Inc.

31. Theodore, J. (2012). Learning organizations, the American employee and manager, and the developmental role of the social sciences. Global Journal of Management and Business Research, 12(4).

32. World Commission on Environment and Development. (1987). Our common future. Oxford: Oxford University Press.

33. York. R., Rosa, E. A., \& Dietz, T. (2003). Footprints on the earth: The environmental consequences of modernity. American Sociological Review, 68(2), 279-300. 


\section{NOTES}

